NBER WORKING PAPER SERIES

THE POLITICAL ECONOMY

OF IMMIGRATION RESTRICTION

IN THE UNITED STATES, 1890 TO 1921

Claudia Goldin

Working Paper No. 4345

NATIONAL BUREAU OF ECONOMIC RESEARCH 1050 Massachusetts Avenue Cambridge, MA 02138 April 1993

I thank Lisa Kao, Boris Simkovich and Marian Valliant for providing superb research assistance, and Lawrence Katz, Jeffrey Williamson, and the participants of the Harvard Economic History Workshop for their helpful comments. Shawn Kantor kindly supplied the wage data by city for the union sample, 1907 to 1923 . This research has been funded by NSF Grant SES-9122782. Prepared for presentation at the conference on Historical Political Economy, NBER, May 20-21 1993. This paper is part of NBER's research programs in Development of the American Economy and Labor Studies. Any opinions expressed are those of the author and not those of the National Bureau of Economic Research. 
NBER Working Paper \#4345

April 1993

\title{
THE POLITICAL ECONOMY \\ OF IMMIGRATION RESTRICTION \\ IN THE UNITED STATES, 1890 TO 1921
}

\begin{abstract}
Anti-immigrant forces almost succeeded in passing restrictive legislation in 1897, but their plan did not ultimately materialize for another twenty years. During that time 17 million Europeans from among the poorest nations came to the United States. This paper explores the economic and political forces that propped the door open for those twenty years, as well as the factors that eventually shut it. Economic downtums and their consequent unemployment almost always brought demands for restriction. The flood of immigrants eventually did result in large negative effects on the wages of native-born workers. But the political clout of immigrants was strengthened by the reinforcing nature of their flows. Cities having large numbers of the foreign born received a disproportionate share of immigrants during the 1900 to 1910 period. After 1910, however, immigrant flows were diluting. This factor and the negative impact of immigrants on native wages were important in the passage of restrictionist legislation, although the rural heartland of America was pro-restriction from the 1890 s.
\end{abstract}

Claudia Goldin Department of Economics Harvard University Cambridge, MA 02138 and NBER 
With the passage of the Emergency Quota Law in May 1921 the era of open immigration to the United States came to an end.' The American policy of virtually unrestricted immigration was transformed, almost overnight, to a quota system that would last until 1965. The change in policy is not hard to explain. The perplexing part of the legislative history of immigration restriction is its timing. More astonishing than the closing of the door in 1921 is that it remained open despite twenty-five years of assault during which 17 million immigrants from among the poorest nations in Europe found retuge in America. This paper details the remarkable set of events that propped the door open and the forces that eventually slammed it shut.

Because the story of immigration restriction is a legislative one, its main players will be Representatives, Senators, and Presidents. But behind the legislative tale are the shifting interests of three groups. The first is organized labor, represented by the American Federation of Labor and the Knights of Labor, and unorganized labor. Owners of capital, joining together, for example, through the National Association of Manufacturers, the National Board of Trade, and Boards of Trade and Chambers of Commerce in numerous ctiles, are the second but the most difficult to categorize. Immigrants, both now and old, are the third.

Controlling segments of these groups united in the 1890 s to form a coalition opposed to unrestricted immigration. The coalition nearly succeeded in the late 1890 s - indeed they were but two votes short - in passing legislation to curtail immigration. Portions of the coaltion switched sides during the first decade of this century and a new force to champion the cause of open immigration - the recent arrivals themselves - emerged. Capital, which had joined the antiimmigrant forces in the economically turbulent 1890 s, threw much of its weight on the side of open immigration in the early 1900s. Congress witnessed several battles over the immigration issue during the twenty years following the first vote on the literacy test in 1897, but none succeeded in ahering the flow of immigration. It has been claimed that in took a world war,

\footnotetext{
'As I will argue later, the abrupt end should more accurately date with the final passage of the literacy test in 1917, since it was a simple step to move from the test to a quota.
} 
Igniling xenophoblc and staunchly nativist sentiment, to pass immigration restriction. There may be some truth to that view, but the analysis in this paper suggests that the declining political power of immigrant groups and falling real wages for lower-skilled workers after around 1910 may have eventually clinched the vote for restriction.

The chronology of immigration restriction will be detailed first. The history is well known and has been recounted elsewhere (Higham 1955, Hutchison 1981, Jones 1992 2nd ed., Taylor 1971). My emphasis will be on shitting coalitions and their economic and poltical bases as inferred trom aggregate economic activity and the votes in Congress. I then move to a more indepth analysis of clty-level wage data by occupation and industry from 1890 to 1923 to ascertain the possible economic bases of support.

The wage data reveal substantial negative effects of immigration for both laborers and artisans, although the effects by industry are less clear. The impact, moreover, appears to have increased from the 1890 to the early 1920 s corresponding to the rise in negative sentiment toward open immigration in the immedlate pre-World War I period. Finally, voting in the House is linked to the strength of the wage effect and to the proportion of the population that was foreign born. The greater was the increase in wages in particular cities, the lower was the percentage of Representatives in the state who voted for restriction. But the greater the percentage foreign born in these cities, the lower the sentiment for restriction in the state. The desire to restrict was, therefore, tempered by the composition of the electorate. Most importantly, and similar to developments in the United States of late, the foreign bom may uttimately have been scapegoats for economic tactors in certain local labor markets.

The Literacy Test

The history of European immigration restriction begins with the movement to pass the 
literacy test, succeeding ultimately in $1917 .^{2}$ Quotas and other types of blanket restrictions were not seriously considered in the House or the Senate prior to $1920 .^{3}$ Of the multitude of regulations considered only two could have seriously restricted immigration - the financial and literacy tests. Only the literacy test received serious deliberation.

Not only was the literacy test given careful consideration, it passed the House on five separate occasions and passed the Senate on four. Further, the House overrode presidential vetoes of the bill twice and on two occasions failed to override by fewer than 7 votes. The Senate overrode a presidential veto once when the test became law in 1917.

The literacy test was to be administered to physically capable adults to assess their ability to read. Although the test varied in the many pieces of immigration legislation in which it was a section, it generally consisted of reading several sentences of the Constitution in any language chosen by the potential immigrant, including recognized dialects. Some of the proposed legislation also required that the immigram be capable of writing the sentences he could read.

2 Immigration was restricted and regulated in various ways in addition to the literacy test and, eventually, quotas, but none was of great quantitative significance. Of most importance is that the restrictions placed on Asians will not be treated in any detail here. See, for example, Higham (1955) for a defense of limiting attention to European immigration. It should be noted, as well, that immigration from the Westem Hemisphere was not restricted by the 1921, 1924, and 1929 quotas, although the literacy test was unaffected by that legislation.

${ }^{3}$ Various influential groups had, prior to the passage of the quotas, petitioned Congress to end immigration for some period of time. The AFL, in December 1918, requested that Congress curtail immigration for at least two years (Higham 1955). During the debates over the quota legislation in the aftermath of World War I several bills were introduced that would have suspended immigration for periods of from three to five years (Hutchison 1981, $p$ 171). Of the mary possible means of restricting and regulating immigration contained in the Immigration Commission Report of 1910 none was a blanket quota of the type eventually adopted in 1921. 1924, and 1929. One suggested means that would have limited the number of each race arriving each year to a certain percentage of the average of that race arriving during a given period of years" (U.S. Senate 1911, p. 47).

' Section 39 of the immigration bill introduced in 1906 contained a financial test that would have required, among other things, that all male immigrants over sixteen years old (or the male head of the household) have \$25 or its equivalent (Hutchison 1981, p. 139). The final version of the 1907 act did not contain this provision. An amount of $\$ 25$ was 2.4 weeks of income for lowerskilled manufacturing labor in America in 1906 and about 9 weeks of income for an equivalent worker in southem and eastem Europe at the time Historical Statistics 1975, series D 778; Simkovich, Taylor, and Williamson 1992). 
Close relettves of an adult male immigrant who was literate were often exempted. Because the chipping companies that brought immigrants across the ocean were responsible for the retum voyege of any who did not meet U.S. immigration standards, it is likely that these companies would have administered a literacy test of their own, in the same way that they screened for heakth violations in European ports.

The literacy test first came to a vote in Congress in 1897 and was overwhelmingly passed by the House and cleared a majority in the Senate (see the chronology in Table 1). At least one other bill was proposed during the debate in the House which could have been even more restrictive and which would have restricted immigration from any pon not having a consular inspection station in Europe.

Several factors operated in the mid-1890s to create a short-lived coalition, yet one that would surface again, In some form, around regulating and restricting immigration. The leadership and members of the American Federation of Labor and the Knights of Labor came out strongly in favor of the literacy test in 1897, but had not done so before. The depression of the 1890 s with its extremely high rates of unemployment, particularty in the manufacturing sector, appears responsible for the change of heart. ${ }^{5}$ But capital, too, turned against immigration.

Industry had depended on immigrant labor and thus the restrictionist sentiment of certain associations of capitalists may seem inexplicable. The labor unrest of the 1880 s and earty 1890 s, fresh in the minds of many, may have been a deciding factor. In addition to a rash of strikes there were particularty odious events, such as the Homestead strike of 1892 and the Haymarket riot of 1886. The business faction that united against immigration in the last two decades of the nineteenth century is not easily categorized (Heald 1953, Wiebe 1962). Its motivation was shortrun, it seems, and it disintegrated rapidly once economic conditions improved, labor unrest

\footnotetext{
5 The AFL letter to Congress in 1898 also argued that "laborers are imported from other countries to reduce our wages and thereby our standard of living" (U.S. Congress, Congressional Record Senate, vol. 31, p. 686). The AFL, like others, was arguing against contract labor and the enticing of immigrants by shipping and railroad companies to emigrate to the United States.
} 
Table 1

Immigration Restriction Chronology: Votes on the Literacy Test

\begin{tabular}{|c|c|c|c|}
\hline Date & Branch of Government & Vote & Notes \\
\hline $\begin{array}{l}2 / 9 / 97 \\
2 / 17 / 97 \\
3 / 2 / 97 \\
3 / 3 / 97 \\
3 / 3 / 97\end{array}$ & $\begin{array}{l}\text { House } \\
\text { Senate } \\
\text { President Cleveland } \\
\text { House } \\
\text { Senate }\end{array}$ & $\begin{array}{l}217-36-102^{2} \\
34-31-25 \\
\text { voto } \\
195-37-123\end{array}$ & $\begin{array}{l}\text { affirmatlve vote on blll } \\
\text { affirmattve vote on bill } \\
\text { overnides presidential veto } \\
\text { takes no action, bill dies }\end{array}$ \\
\hline $\begin{array}{l}1 / 17 / 98 \\
12 / 14 / 98\end{array}$ & $\begin{array}{l}\text { Senate } \\
\text { House }\end{array}$ & $\begin{array}{l}45-28-16 \\
101-104-150\end{array}$ & $\begin{array}{l}\text { affirmative vote on bill } \\
\text { negative vote on consideration } \\
\text { of bill }\end{array}$ \\
\hline $5 / 27 / 02$ & House & no vole found & $\begin{array}{l}\text { affirmative vote on bill, literacy } \\
\text { test dropped in House-Senate } \\
\text { conference }\end{array}$ \\
\hline 6/25/06 & House & $128-116$ & $\begin{array}{l}\text { vote to remove literacy test from } \\
\text { Immigration bill and to set up } \\
\text { Immigration Commission }\end{array}$ \\
\hline $4 / 19 / 12$ & Senate & $9-56-30$ & $\begin{array}{l}\text { vote was to strike the literacy } \\
\text { test from the bill; affirmative vote } \\
\text { on bill, sent to conference }\end{array}$ \\
\hline $12 / 18 / 12$ & House & $179-52$ & $\begin{array}{l}\text { affirmative vote on bill, sent to } \\
\text { conference }\end{array}$ \\
\hline $\begin{array}{l}2 / 14 / 13 \\
2 / 19 / 13\end{array}$ & $\begin{array}{l}\text { President Taft } \\
\text { House }\end{array}$ & $\begin{array}{l}\text { veto } \\
213-114-54\end{array}$ & fails to overnide \\
\hline $\begin{array}{l}1 / 2 / 15 \\
1 / 15 / 15\end{array}$ & $\begin{array}{l}\text { Senate } \\
\text { House }\end{array}$ & $\begin{array}{l}50-7-39 \\
227-94-103\end{array}$ & $\begin{array}{l}\text { affirmative vote on bill } \\
\text { affirmative vote on conference } \\
\text { report of bill }\end{array}$ \\
\hline $2 / 4 / 15$ & $\begin{array}{l}\text { President Wilson } \\
\text { House }\end{array}$ & $\begin{array}{l}\text { veto } \\
261-136-26\end{array}$ & fails to override \\
\hline $\begin{array}{l}3 / 30 / 16 \\
12 / 14 / 16\end{array}$ & $\begin{array}{l}\text { House } \\
\text { Senate } \\
\text { President Wilson }\end{array}$ & $\begin{array}{l}307-87-39 \\
64-7-25 \\
\text { veto }\end{array}$ & $\begin{array}{l}\text { affirmative vote on bill } \\
\text { affirmative vote on bill }\end{array}$ \\
\hline $\begin{array}{l}2 / 1 / 17 \\
2 / 5 / 17\end{array}$ & $\begin{array}{l}\text { House } \\
\text { Senate }\end{array}$ & $\begin{array}{l}287-106-40 \\
62-19-5\end{array}$ & $\begin{array}{l}\text { overrides veto } \\
\text { overnides veto }\end{array}$ \\
\hline
\end{tabular}

- Hutchinson reports those not voting as 125 not 102.

Sources: Hutchinson (1955); U.S. Congress, Congressional Record, 62nd, 63rd, and 64th sessions, House and Senate.

Notes: Roll call votes count those not voting whereas non-roll call votes have only pro and con. 
subsided, and wage decreases from immigration were more apparent.

The face of immigration changed rapidly in the 1890s, moving from northern Europe to southern, central, and eastern Europe. Whereas the new immigrants were 35 percent of the total flow in 1890, they were 56 percent in 1896, although the flow was of comparatively modest size in the mid-1890s, a product of economic depression (see Figures 1 and 2). ${ }^{\circ}$ it has been claimed that the new immigrants were too recent and too few to motivate policy (Higham 1955). A reading of the Congressional Record affords ample reason to disagree with this claim, but not with a related assertion that the new immigrants were too recent and too fow to influence policy. ${ }^{7}$ But they would be fortified by numbers and unified by fear in a very brief period.

President Cleveland vetoed the immigration legislation in 1897 because it contained the literacy test, and although the House voted to override his veto, the Senate took no action and the bill died. Just one year later, in 1898, a similar immigration law was proposed in Congress. In this case the bill cleared the Senate but failed to pass the House by 3 votes, which had just a year before given it overwhelming support. The flip-flopping that took place on this important issue extended to the executive branch as well. Although Cleveland vetoed the act in 1897 his successor, McKinley, ran on a Republican platform that called for the literacy test. Thus the binding constraint in 1898 was the House, whereas the constraint just a year before was the Senate. Had just 2 Representatives changed their vote to pro from con, the literacy test would

\footnotetext{
- New immigrants are those from southem and eastern Europe. I have included the nonGerman speaking emigrants from Austria in eastem Europe.

7 According to Higham (1955) the Immigration Protection League, organized primarily by the older immigrant groups in the late 1890s, led the defeat of the 1898 literacy requirement in the House.

- Of the 45 yeas in the Senate in 1898, 23 voted affirmatively in 1897, 6 had voted negatively, 9 had been recorded as absent, and 7 were new members of the Senate. Had all those present in both 1897 and 1898 voted as they did in 1898, the vote would have been 37 for and 22 against. The new members of the Senate in 1898 split their votes about even for the test in 1898. Thus it was the disproportionate exh of the negative votes, primarily Democrats, that increased the strength of the pro-restriction coalition, primarily Republican. See Higham (1955) who claims the bill passed the Senate in 1898 along party lines.
} 
have become law in 1898.

The literacy test passed the House again in 1902 but was dropped in House-Senate conference, and was not agaln incorporated into an immigration act until 1906. Through the political maneuvering of Pepresentative Joe Cannon, Speaker of the House, the House voted in 1906 to remove the literacy test and set up the Immigration Commission to explore the matter in greater depth. The now-famous 42 volume Report of the Immigration Commission was issued in 1910. In it was a call for a literacy test to regulate the flow of immigrants. A majority of the Commission favor the reading and writing test as the most feasible single method of restricting undesirable immigration . . . The Commission as a whole recommends restriction as demanded by economic, moral, and social considerations' (U.S. Senate 1911, vol. I, p. 48). On the heels of the report, the literacy test was reintroduced in Congress in 1912

From 1898, the previous vote on the literacy test in Congress, to 1912, the next vote, were 14 years of extraordinary immigrant flow particularty from southern and eastern Europe. The relative silence in Congress on the literacy test is all the more curious. It might be claimed, however, that the halls were actually not silent. There had been a vote in 1902 and the test was almost incorporated into legislation in 1906. With the creation of the immigration Commission, Congress may have felt obliged to wait for its report since its directive was to assess immigration restriction. Another interpretation is that shifting imerests were at work. Although organized labor remained against unrestricted immigration, capital had shifted decisively. Looking more toward its long-run interests in holding down wages, capital put aside its fears that labor unrest would be fueled by foreign agitators. Perhaps of most importance was the emergence of a plvotal group in the form of the new immigrants, who were vocal and rapidly gaining the franchise. 10

\footnotetext{
- The assumption here is the President McKinley, having run on a platform advocating the literacy test, would not have vetoed the bill.

${ }^{10}$ The new immigrants have been portrayed by many as a potent force in big city politics during the Progressive era, but recent data on the percentage of the foreign bom in major chites who were eligible to vote raises questions about their strength (see Keyscar, in progress). Keyssar looks as the percentage naturalized of males $\geq 21$ years and finds that between $40 \%$ and
} 


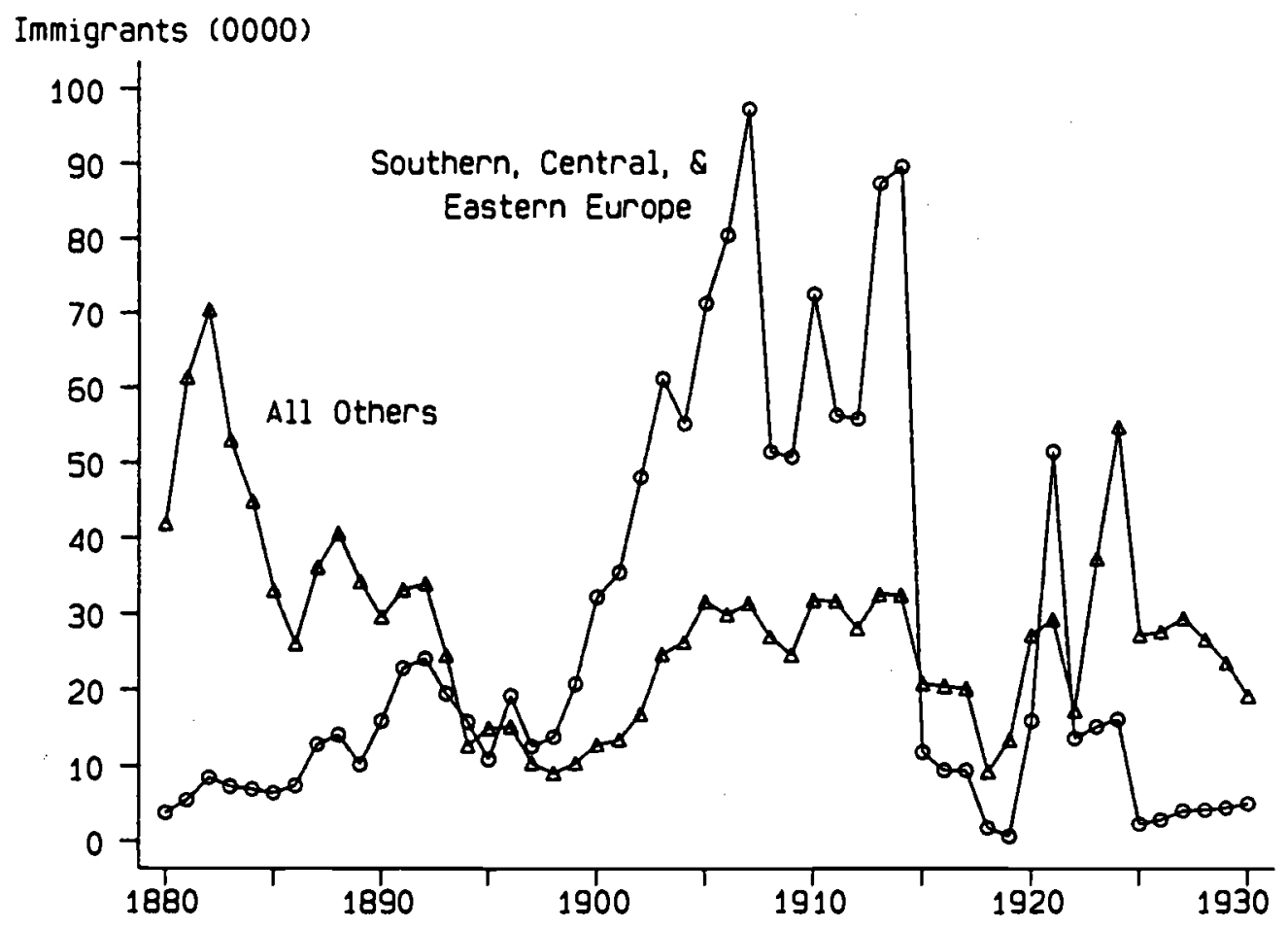

Figure 1: Immigration, 1880 to 1930

Source: U.S. Bureau of the Census (1975), series C 89-119. 


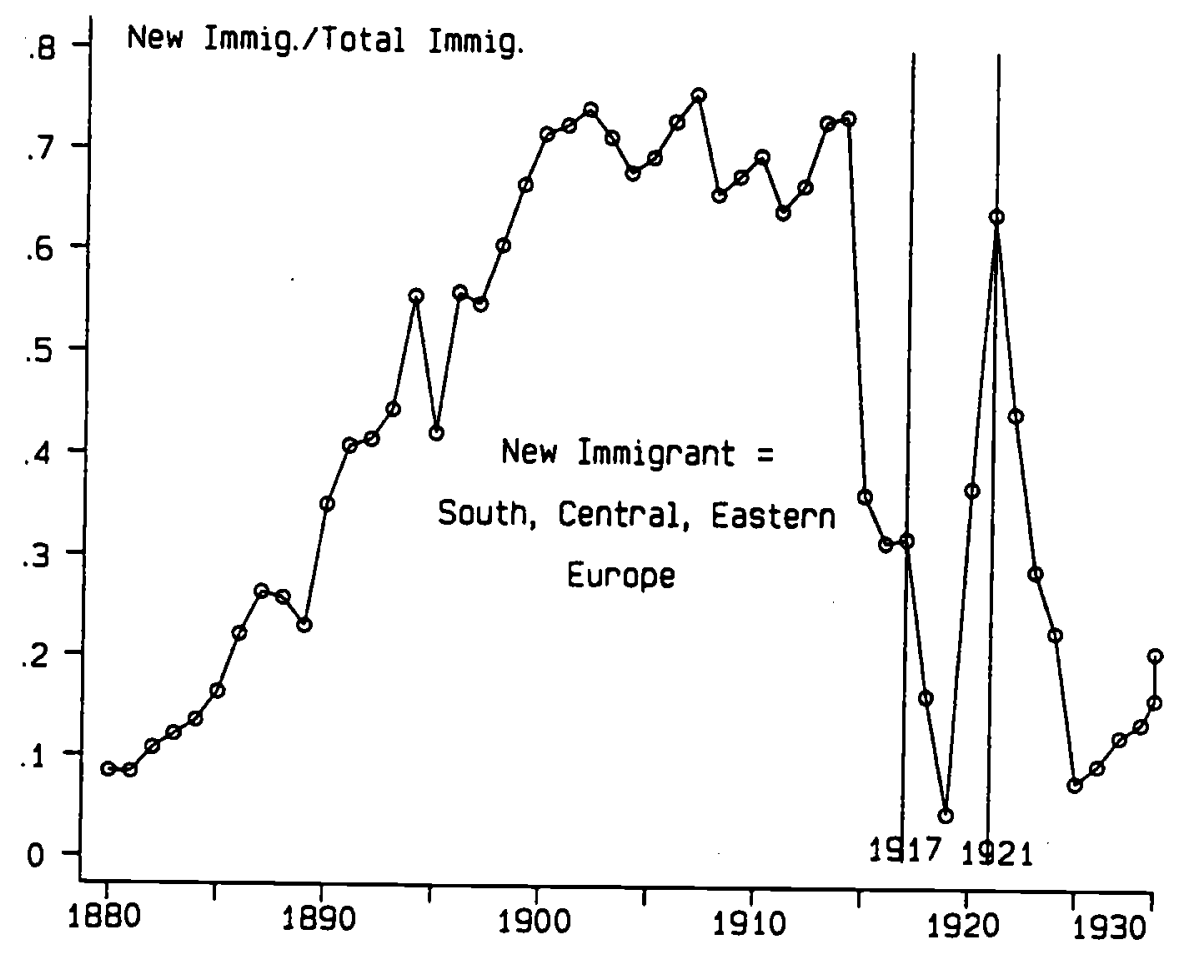

Figure 2: Proportion of Immigrants from Southern, Central, and Eastern Europe, 1880 to 1930

Source: U.S. Bureau of the Census (1975), series C 89-119. 
Both the Senate and House passed the literacy test again in 1912 only to have it vetoed by lame-duck President Taft. The House failed by just 6 votes to override the veto. Had in been able to override, the test would have become law since the Senate vote was 86 percent in favor of the amendment on the literacy test. The literacy test was reintroduced in 1915, passing the Senate by a wide majority and the House by enough to override a veto but with a large segment not voting. President Wilson, an ardent Progressive remembering his promise to immigrants in the 1912 election, vetoed the legislation, and the House failed to override $i$, this time by just 5 votes. In 1916 the House and Senate once again passed a bill containing the literacy test and finally, in 1917, both houses successfully overrode Wilson's second veto. The literacy test became law.

The literacy test was merely an overture to the Emergency Quota Act passed in 1921, the Immigration Act of 1924, and, eventually, the National Origins Act passed in 1929. Although the quotas were plausibly more potent than the literacy test, the test could have imposed considerable constraints particularly on the new immigram groups. How much of a constraint depends on the type of test, the sending country flows, and the period considered.

As initially conceived in 1897 , the literacy test involved reading and writing a short passage of the U.S. Constitution and barred illiterate adult males and their accompanying family members. At that time it was believed that the test would have barred 25 percent of all recent arrivals, atthough more than 40 percent of the newer groups would have been." More precise estimates were compiled for the Immigration Commission Report. According to the Report, data collected by the U.S. Commissioner-General of Immigration from the self-reported statements of

$70 \%$ were, but that states often had residence requirements that the mobile foreign born often could not meet. The evidence presented here supports, in principle, the assertions of the older linerature. The foreign born might have been an even more potent force had naturalization been faster and had various states had more lenient residency requirements.

"During the debate on the immigration act of 1898, Senator Fairbanks of Indiana inserted data in the Congressional Record showing that about 25 percent of immigrants (14 years old and over) arriving from 1895 to 1897 were illiterate. Illiteracy was declared by the immigrant and no official test was given (U.S. Congress, Congressional Record 1898, Senate, vol. 31, p. 515). 
immigrants upon arrival indicated that 33.4 percent of eastern European and 44.9 percent of southem European immigrants (14 years and older) arriving during the period from 1899 to 1910 were illiterate. ${ }^{12}$ Thus the test would have reduced the number of all new immigrant groups by 37.4 percemt in 1907 at the helght of immigration. The constraint would have been less in the 1920 s due to rising literacy in eastem and southem Europe, although the test could have been made more difficult. ${ }^{13}$

For the entire 1905 to 1914 period, a decade of immigrant flows of more than 1 million per year, the literacy test would have restricted immigration from southem and eastem Europe to about 445,000 annually when the flow was, in actuality, $712,000 .^{14}$ But the eventual quotas were far more restrictive. The 1921 act limited southern and eastem Europeans to 156,000 and the 1924 and 1929 acts lowered it further to just over 20,000, a mere trickle. Put in terms of total immigration, from 1905 to 1914730,000 would have entered each year had there been a literacy test, whereas the 1921 act called for about half that number. The 1924 and 1929 acts stipulated

\footnotetext{
12 Female immigrants were less literate than male immigrants. Because many versions of the literacy test allowed the illiterate family members of a literate adult male immigrant to emigrate, the constraint would have been less than calculated on the basis of the aggregate data. But younger adults were more literate than older adult immigrants and since the Immigration Commission data group all ages, this factor would tend to bias the calculation in the other direction. The data trom the U.S. Commissioner-General of Immigration in the Immigration Commission Report (1911, vol. 1, p. 99) differ, otten radically by country, from those reported in the Congressional Record (U.S. Congress, Senate, 1898, vol. 31, p. 516) for a somewhat eartier period of time. But the data in the Immigration Commission Report are consistent with estimates I have computed using the 1910 Public Use Micro-data Sample (PUMS).

13 Primary school enrollmemt had been rising secularty in Maly, Spain, Yugoslavia, and Rumania across the latter half of the nineteenth cemtury and exploded in Russia after the revolution. See, for example, the data in Easterlin (1981).

14 Emigration to the United States from Europe could have slowed in the 1920 s as conditions improved in certain European countries relative to those in the United States. Wage data collected for a project on international economic convergence (Simkovich, Taylor, and Williamson 1992) indicate that haly, the only new immigrant county in the data set, improved its real wage position relative to the United States during the 1900 s to 1920 s period. In 1910, for example, the ratio of halian to American real wages for unskilled laborers was 0.29 , but by 1925 it was 0.48 . h should also be noted that even though gross immigration was 6.71 million from 1908 to 1914, many immigrants retumed home. The net immigration figure is 61 percent of the gross or 4.07 million (Wilicox 1931, p. 88).
} 
amounts that were one-quarter to one-fith the hypothetical flows. Thus the literacy test, even as conceived in 1897, would have imposed rather stringent restrictions on the new immigrants, although not nearly as harsh as those eventually imposed by the 1929 National Origins Act.

The votes on the literacy test indicate the shitting coalitions mentioned earlier. The first vote in the House, in 1897, brought southern and urban-nontheastern interests together in opposition to the test with virtually the rest of the country favoring it. $^{15}$ The South clung to the hope that immigrants would eventually settle there; the northeast voted its constituents' personal interests and it continued to do so on this point into the twentieth century. By the second vote, in 1912 and that in 1913 to override the veto, the South finally acknowledged that immigrants would never flock there, and anti-foreign sentiment on the basis of race had emerged. With the exception of Louisiana, the South was united in favor of restriction and only portions of the urban northeast and midwest were firmly in opposition to it. The election of 1916 removed enough opponents to the test that the override of the presidential veto was assured. In fact, had the vote been taken of those in office at the previous session, it would not have passed over Wison's veto. Party affiliation had nothing to do with the shitt in the vote. Those opposed to the literacy test had been voted out of office.

The fact that there were three votes on the literacy test by three successive seatings of the House enables one to see how the changed composition of the electorate altered the outcome (see Table 2). ${ }^{10}$ Comparing first the votes of those Representatives who voted in both the 62nd (1912/13) and 63rd (1914/15) Congresses, 74 percent voted for the literacy test. Thus the incumbent members of the House were overwhelmingly in favor of restriction in 1915. The

15 Of the 37 negative votes, 25 were cast by southerners. Three from New York City Joined them together with 8 others from urban areas in the northeast. One additional Representative, trom Wisconsin, voted against the test (U.S. Congress, Congressional Record House, vol. 31?, p. 2947 ).

${ }^{10}$ I am looking only at the voting record of the House because the Senate passed the test by wide enough margins in 1912/13, 1914/15, and 1916/17 to override a Presidential veto. The Senate would be expected to be more supportive of restrictive immigration than the House, in which certain Representatives were elected in districts populated by the new immigrants. 


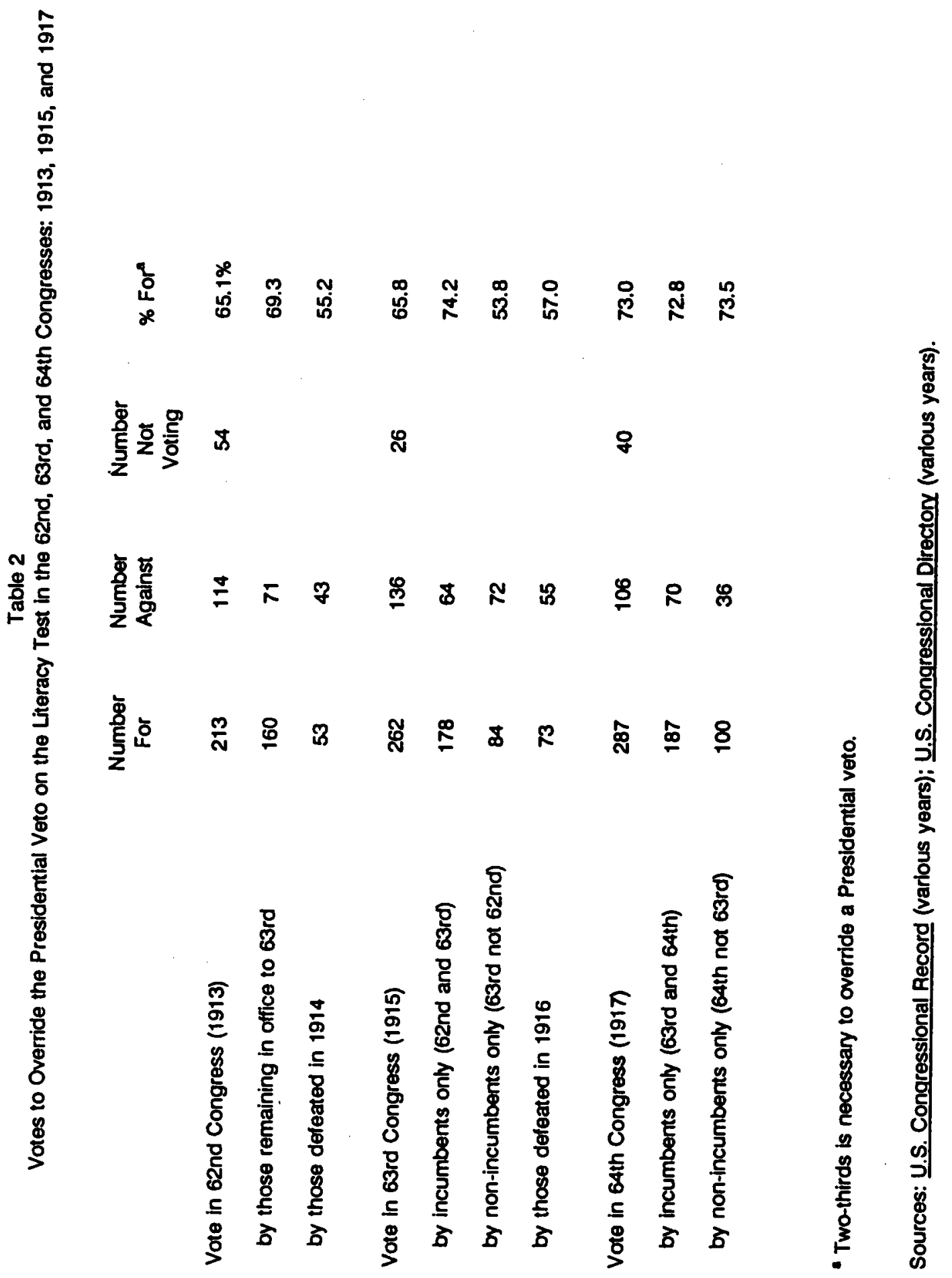


recently seated members of the House did amass a majority in favor of restriction, but they did so just barely. Only 55 percent voted for the test in 1915, clearty not enough to override a presidential veto. Thus it was the newly elected Representatives who held the literacy test at bay, suggesting that big-city districts had changed composition. The new immigrants themselves, it seems, managed to elect Representatives who voted dispropontionately against the literacy test. But if this were the only change in the House, the vote would have become less in favor of the act over time. Rather, the percentage voting in favor remained at 65 percent. Those who were voted out of office were in favor of the keeping the door open to the same degree as those who took their place. Thus the vote in 1913 would have cleared the two-thirds needed to override had only those who kept their seats to 1915 voted. Those who were defeated in 1914 voted far more decidedly against restriction, although with a majority in favor of the literacy test.

The old guard in the 1913 and 1915 votes were pro-restriction. The young turks and those who suffered defeat at the polis in 1914 were less restrictionist. The new members - the young turks - hailed primarily from the large and industrial cities of the northeast and midwest, whereas those defeated in 1914 carne from small to middle-sized towns across America. Those suffering defeat, therefore, were replaced by Representatives far less in favor of open immigration. But the new turks were able to make up the difference and prop the door open. America had become more biturcated along the lines of open immigration, and it was redistricting in 1914 that rescued the pro-immigration bloc. ${ }^{17}$ Without it, the anti-forces would have won. The increased population of the nation's big and incustrial cities, with its largely immigrant composition, was

17 The possibility that it was redistricting is by inference only. There were 45 additional Representatives seated in the 63rd Congress than in the 62nd Congress, and there were 43 more Representatives present for the vote in the 63rd than in the 62nd Congress to overide the President's veto (see Table 1). Much of the redistricting took place within states, it appears. A tabulation of Representatives by state does not reveal much difference between the two Congresses. But New York City, for example, gained 7 Representatives. Among those who were not seated in the 62nd Congress but who voted in the 63rd, there were 9 from New York City who voted against the test. Two Representatives from New York City were not reelected, one of whom was against and one of whom was for the test. Three of the newly elected Representatives were from Philadelphia which only lost one seat from the 62nd to the 63rd Congresses. Chicago, however, made no net gain. 
responsible for keeping the anti-immigrant forces just below the two-thirds majority needed to override. All changed by 1917, however, when there was no relationship between incumbency and the vote on the literacy test. All in the House - save those whose seats were in the center of the nation's largest cities - voted overwhelmingly for it regardless of time in office and party affiliation.

The Economic Basis for Immigration Restriction

Almost all serious calls for the literacy test were preceded by economic downturns, some of major proportion, and few economic downtums of the era were not accompanied by a call for restriction in the halis of Congress. Unemployment and labor unrest were clearly in the minds of legislators in the 1897 and 1898 votes, and economic conditions had worsened just as the 1915 literacy test came to a vote. The major recession just following World War I was a factor in the Emergency Quota Act. But the clamor for restriction at particular junctures in our history must have been reinforced by other economic forces, some national and long run in nature and some specific to the cities and periods that experienced the greatest influxes. Immigrants, no matter where they went in the United States, had economic effects on those already in the country no matter where they lived and worked. But the initial impact that immigrants had on wage levels of their close substitutes in production must have been greatest in the local labor markets to which the immigrants originally went and in which most remained. The long-run story of general wage rate changes with the flood of immigrants since the late 1840 s is one of enormous importance on an international scale. ${ }^{10}$ That most relevant to the political economy of restriction is somewhat of a more short-run tale.

The literacy test was introduced and gained momentum because immigration in the $1890 \mathrm{~s}$ had shifted to ethnic and national groups whose schooling levels and living standards were

\footnotetext{
18 See Hatton and Williamson (1992) on the general issue of wage rate changes with largescale immigration on an international level.
} 
distinctly below those of previous groups. They were, moreover, disproportionately male and were often "birds of passage," who spent only brief durations in America. Such individuals were a perceived a threat to the American working man. By toiling long hours and bringing living standards from low-wage countries, they probably did lower the wage-hours offer curve by more than an equivalent increase in native-born workers would have. Moreover, because they frequently lacked rudimentary skills in reading and writing, and more often in English, they may have earned even less than competitive forces would have dictated. ${ }^{19}$ These were centainly the claims of many observers of the day - Progressives, conservatives, and labor movement organizers alike. Athough each group had its own solution, a dominant one was to restrict immigration on the basis of literacy.

Occupations and Destinations of Immigrants, 1890 to 1920

Certain occupations and industries were disproportionately composed of immigrants whereas others were not. If recently-arrived immigrants were more closely substitutable for other forelgn-born workers and lesser-skilled workers than for native-born higher-skilled workers, then the wage effects should be more negative in industries and occupations having a large percentage foreign born and lesser skilled. The percentage of the labor force that was foreign bom by industry and for selected occupations in 1910 is given in Table 3. The foreign born are divided into three groups - all foreign born, the new immigrants, by which is meant those from eastern, central, and southern Europe, and among the new immigrants those who emigrated within the 10 years preceding the 1910 census, what are termed "recent" immigrants.

All manufacturing employments were more heavily populated by immigrants than was the male labor force as a whole, although a substantial fraction of the differential is accoumted for by the disproportionate employment of native-born workers in agriculture. Excluding the agricultural

19 See, for example, Hannon (1982) for empirical evidence on the extent of labor market discrimination against immigrants during the late nineteenth century. 


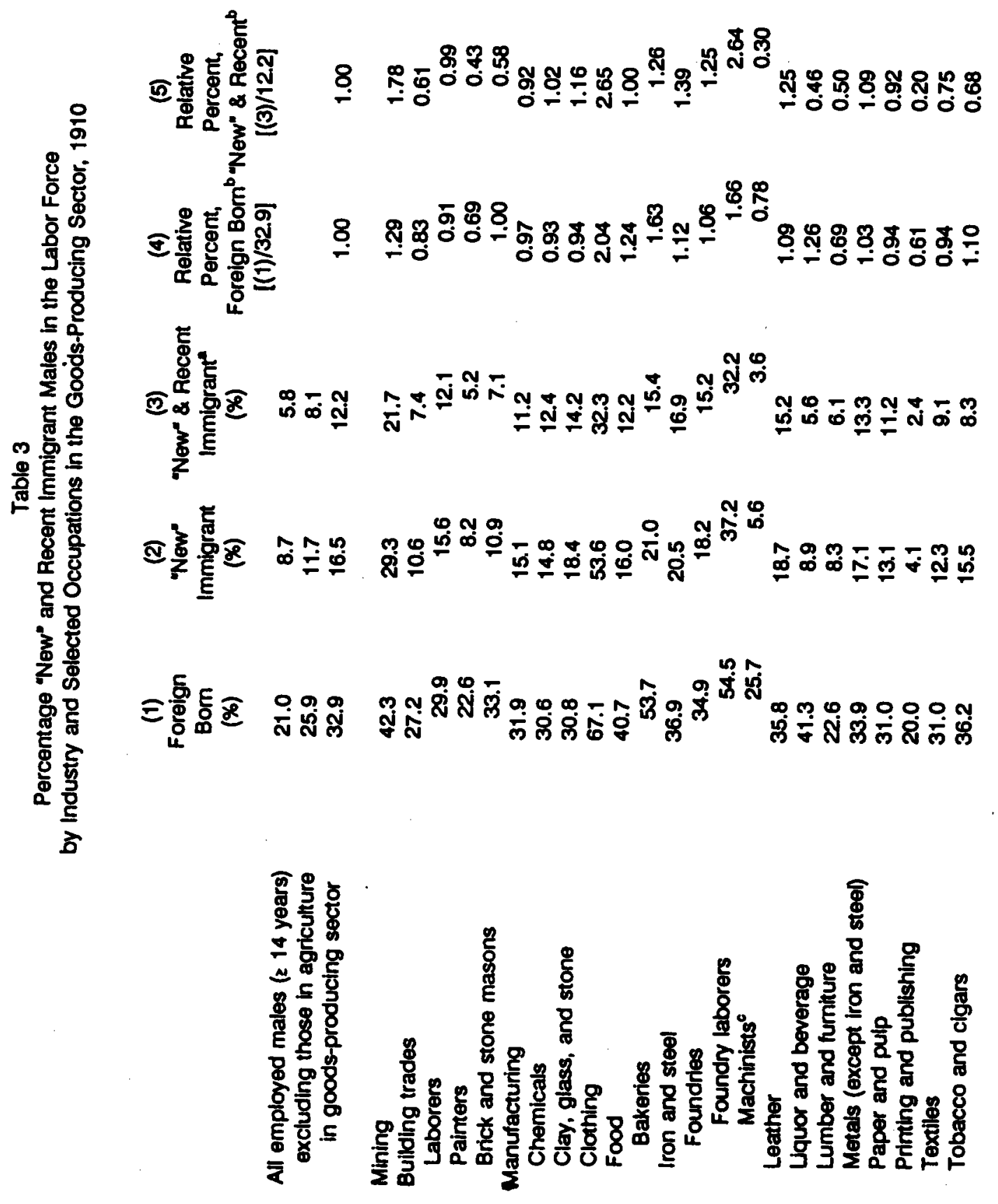




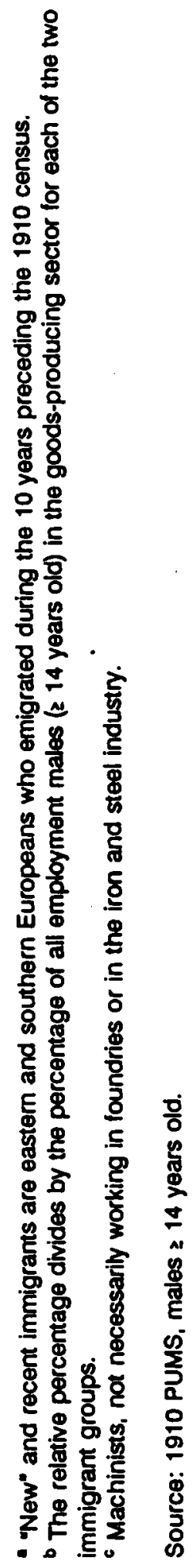


sector, foreign born workers were 1.4 times as likely to have been in the goods-producing sector than were native-born workers, and the new immigrants were almost 1.6 times as likely. ${ }^{20}$ Among the industries most populated by the new and recent immigrants were clothing, mining, and iron and steel. But there was substantial variation in the ethnic backgrounds of workers within industries; in foundries, for example, 32 percent of the laborers were of the new and recent group of immigrants but only 4 percent of the machinists were.

Immigrants went disproportionately to the nation's largest cities but so did all Americans during the period under study. Despite the notion that immigrants, particularty from 1900 to 1914, crowded themselves into a handtul of America's urban centers, they were in fact extremely disbursed across all cities regardless of size. ${ }^{21}$ Indeed, the change in the foreign born population from 1900 to 1910 was, on average, the same across almost all deciles of the size distribution of cities in 1900. The 15 cities with the largest and smallest increases the proportion foreign born in their populations are given in Table 4, part A for 1890 to 1900 and 1900 to 1910. No city in the top decile (decile $=10$ ) is included in the 15 having the largest increases from 1890 to 1900 , and there are many small cities represented among the ranks of those accumulating the foreign born at a faster rate than they accumulated native-born residents. And while there is some repetition in the top and bottom lists across the decades, there is also a lot of movement. Immigrants went to different cities in different decades. They went where there were jobs and, as will be demonstrated in Table 5, they went where their eaming power would be highest.

Also of importance in assessing the political econormy of immigration restriction is whether immigrants went to areas already populated by immigrants. To the extent that immigration begot immigration," certain clites and Congressional districts within them would have become

20 The goods-producing sector is mining, manufacturing, and construction.

21 The one exception - and it is an important one - is New York City. There are 143 cities in the 1890 to 1900 sample and 127 in the 1900 to 1910 sample. (These are the cities in the BLS wages and hours studies for the various time periods.) The eartier sample includes more small cities, although the deciles have been recomputed for each decade. 
Table 4

Changes in the Proportion Foreign Born by City, 1890 to 1920

A. Fifteen cities with the largest and smallest increases in proportion foreign born in the population ( $\triangle F B)$ : 1890 to 1900 , and 1900 to $1910^{\mathrm{A}}$

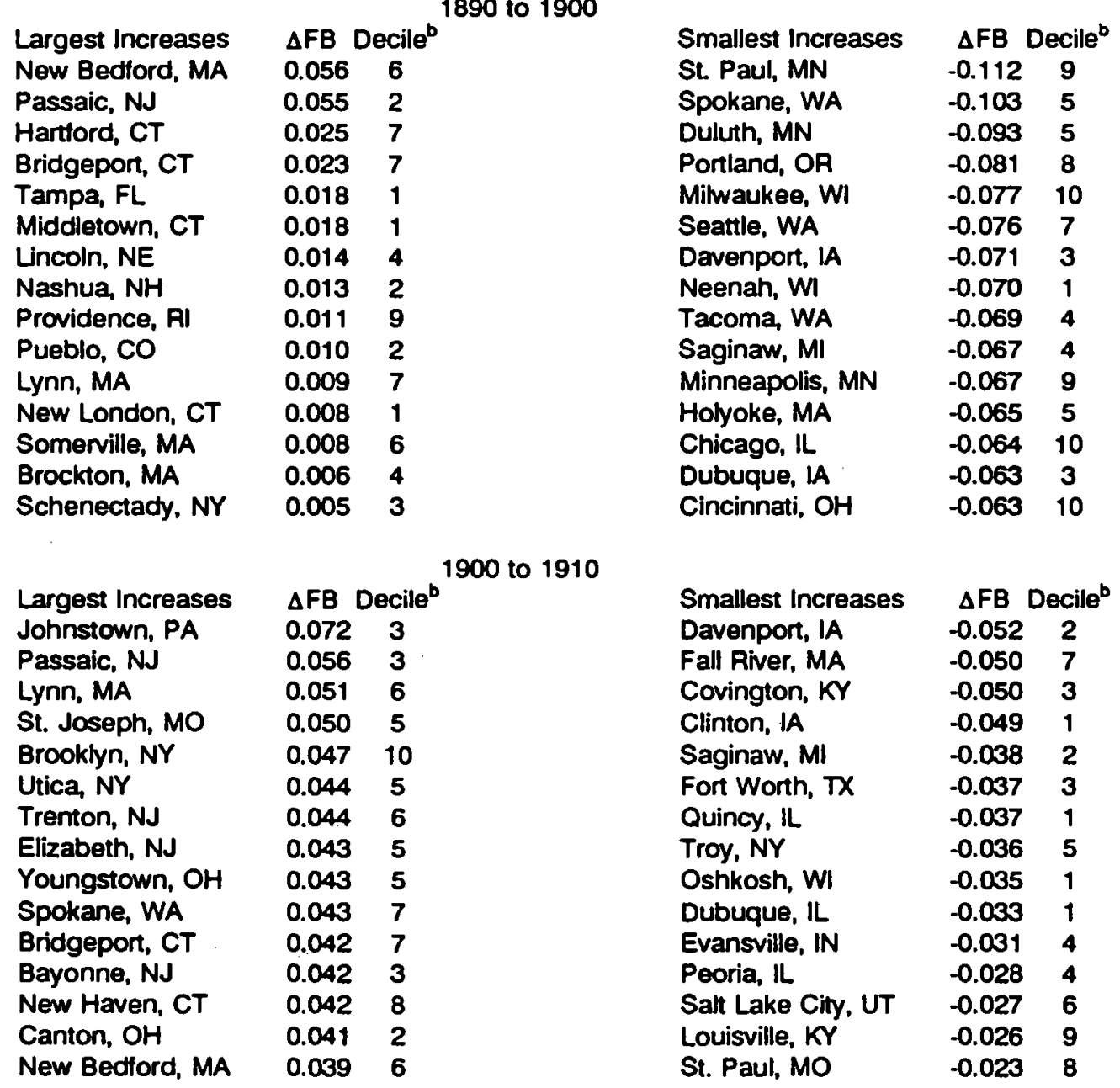

B. Regression of Difference in $\%$ Foreign Born between $t$ and $(t+10)$ on $\%$ Foreign Born in Year $t^{d}$

$\begin{array}{lcccccc} & \begin{array}{c}\text { Coeff. (t-stat.) on } \\ \text { \% Foreign Born }\end{array} & \text { No. Obs. } & A^{2} & \begin{array}{c}\text { Dept. Variable Mean } \\ \text { Unwted. Wied. }\end{array} \\ 1890 \text { to } 1900 & -0.135(-10.4) & 127 & 0.68 & -0.0296 & -0.0373 \\ 1900 \text { to } 1910 & 0.192(1.86) & 127 & 0.27 & 0.0045 & 0.0131 \\ 1910 \text { to } 1920 & -0.119(-11.2) & 115 & 0.52 & -0.0298 & -0.0390\end{array}$


C. Regression of Difference in $\%$ Foreign Born between $t$ and $(t+10)$ on Log of Population in Year $t^{d}$

Coeff. (t-stat.) on

Log Population

No. Obs. $\mathrm{R}^{2}$

1890 to 1900

$-0.0041(-3.20)$

127

0.52

1900 to 1910

0.0053 (4.26)

127

0.42

1910 to 1920

$-0.0057(-5.31)$

115

0.19

- The citles are those in the sample for the wage regressions. There are 142 cities for 1890 to 1900 and 127 for 1900 to 1910. The change in the proportion foreign born in the population is calculated as (e.g. 1900 to 1910): percentage (white) foreign born in 1910 - percentage (white) foreign bom in 1900. It is a percentage point change and is identical to the dependent variable in the wage regressions in Table 6.

'The city's decile is in the distribution of cities by population for 1900. A 10 means the top decile and a 1 is the lowest.

'The city's decile is in the distribution of cities population for 1910.

d All regressions are weighted by the population in the base year. The 1890 to 1900 and 1900 to 1910 regressions also contain regional dummy vartables; that for 1910 to 1920 does not, at present.

Sources:

U.S. Bureau of the Census, Census of Manufactures (various years).

U.S. Bureau of the Census, Census of Population (various years). 
even more disproportionately immigrant in makeup and thus more inclined to oppose immigration restriction. Part $B$ of Table 4 reports the results of the regression of the difference in the percentage foreign born across a decade on the percentage foreign born in the earlier year, that is $\Delta\left[\%\right.$ Foreign Born $\left.{ }_{R+1+10}\right]$ is run on $\%$ Foreign Born. Interestingly, the coefficient is negative for the 1890 to 1900 and 1910 to 1920 decades, but positive for the 1900 to 1910 decade."2 Immigration was reintorcing or concentrating in its impact from 1900 to 1910. Thus immigration restriction was held at bay during the largest immigrant flows because the new immigrants were able to capture various Congressional districts. By the 1910 to 1920 decade, however, the flows had a more diluting impact. Also note that only during the decade of the greatest immigration, that from 1900 to 1910 , did immigrants flow into America's cities at the same rate that native-bom Americans populated the same urban areas. The percentage foreign born actually fell during the 1890 to 1900 and 1910 to 1920 decades in the cities under study. Similar notions are apparent in part $C$ of Table 4. During the 1890 to 1900 and 1910 to 1920 decades, the percentage foreign born in the urban population declined where population grew, but the reverse occurred from 1900 to 1910. Only in the 1900 to 1910 decade did the fastest growing cities also increase their population share of the foreign born. These burgeoning urban areas gained Representatives who held the pro-restriction movement at bay, at least for a while.

Wage Data by City. 1890 to 1923

Economists have, for some time, pondered the wage effects of the enormous influx of less skilled workers in the first two decades of this century. Paul Douglas's (1930) pioneering volume on wages from 1890 to 1926 concluded that real wages in manufacturing rose by 8 percent or only 0.32 percent average annually from 1890 to 1914, the period of greatest immigration. The increase from 1919 to 1926, according to Douglas, was an astounding 3.3 percent average

\footnotetext{
22 The same cities have been used for the 1890 to 1900 and 1900 to 1910 regressions. There are twelve fewer cities for the 1910 to 1920 regression.
} 
annually, whereas that in real wages in the several decades belore 1890 was more on the order of 1.5 percent average annually. ${ }^{23}$ By implication, then, immigration had decreased the earning power of manufacturing workers.

But Douglas's findings were questioned by Albert Rees whose construction of a new consumer price index altered Douglas's central conchusion. According to Rees's estimates, real wages rose by 40 percent from 1890 to 1914 or 1.4 percent average annually (1975, 1 st publ. 1961, p. 120). By implication, immigration had not ahered the course of real wages in the manufacturing sector. The aggregate economy, it appeared, had enormous absorptive capacity for new workers. ${ }^{24}$

But even Rees's wage data, when contrasted with those for "lower skilled workers, suggest that immigration depressed wages. Figure 3 graphs the data from Rees for manufacturing workers (total and union) and those from Coombs for "lower skilled" workers. ${ }^{25}$ Although the Rees data increase at about the same rate for the entire 1890 to 1914 period, that for the "lower skilled" workers does not. In slows down in its increase, flattens out, and then declines sometime after 1907. Note that the unionized workers series, which is for those in manufacturing, is quite anomalous with respect to the other two series. Not only does k remain

23 See Douglas (1930) whose series are reproduced in U.S. Bureau of the Census (1975), series D 766 for nominal wages and E 185 for the price index.

24 This is also a conclusion of Hatton and Williamson (1992) based, in part, on Williamson (1982) who concludes, on the basis of the computable general equilibrium model, that despite the generally large absorptive capacity of the economy, it was lowest around the World War I period.

Athough Rees (1961) and Douglas (1930) used data for a large group of manutacturing workers, one might want wages for only unskilled manulacturing workers. One wage series for such workers shows a far stower growth of hourty wages from 1890 to 1914 than for all manulacturing workers and an even slower one during the period of peak immigration, from 1900 to 1914. Real hourty wages of less-skilled manulacturing workers increased by 0.709 percent average annually trom 1890 to 1914 , and by 0.566 percent average annualty from 1900 to 1914 (David and Solar 1977).

25 These data are from Historical Statistics, series D 766, 768, and 778 for the wage series. Rees's cost-of-living index (series E 186) is used for 1890 to 1914 and is spliced to Douglas's (series E 185) for 1914 to 1926. I credit the series to Rees because it was his revision of the deflator that altered Douglas's central finding that wages were not depressed during the period. 


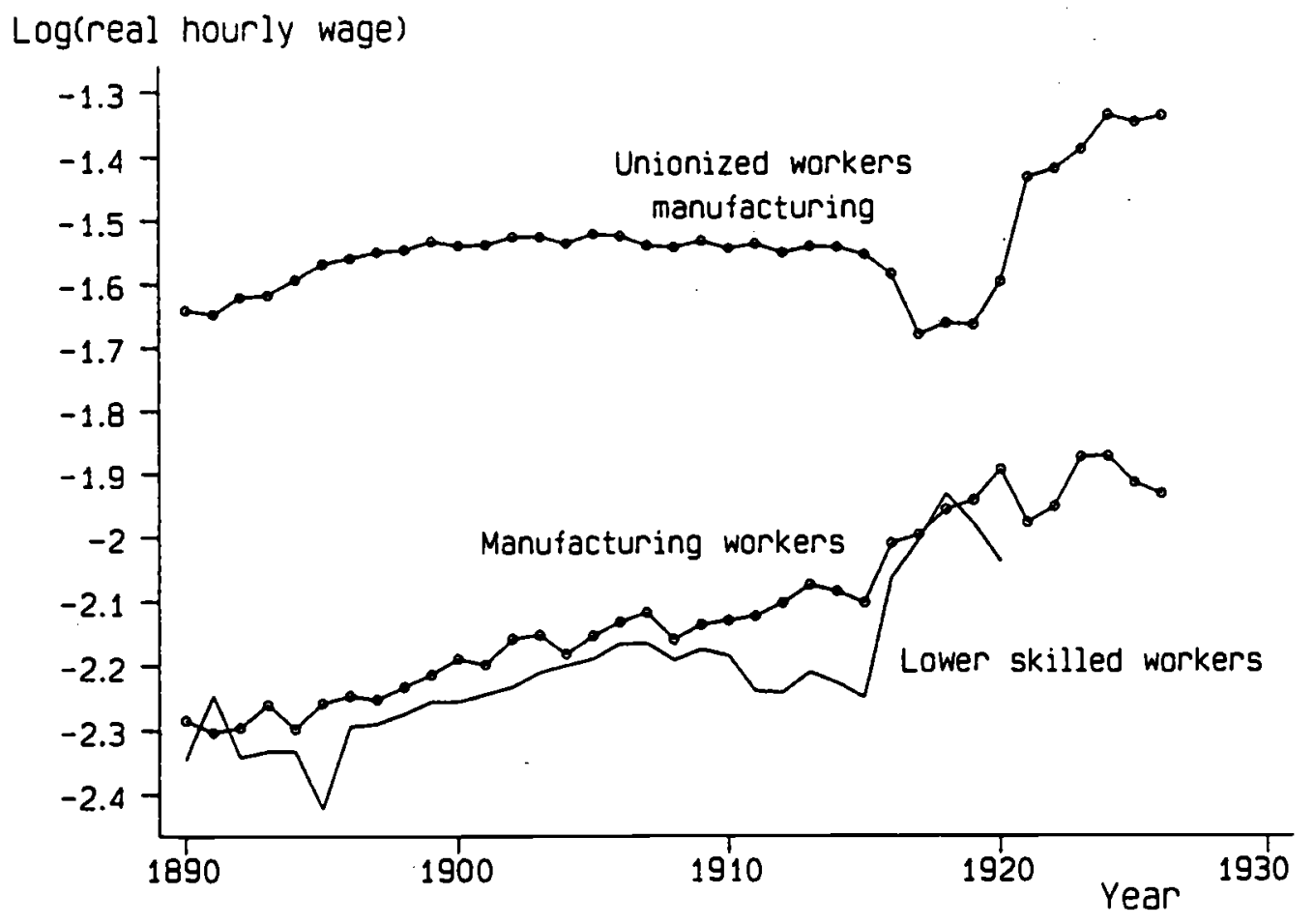

Figure 3: Log of the Real Hourty Wage, 1890 to 1930

Source: Historical Statistics (1975) series D 766, 768, and 778 for the wage series. Rees's cost-of-lwing index (series E 186) is used for 1890 to 1914 and is spliced to Douglas's (series E 185) for 1914 to 1926. 
level from 1900 to 1914, it decreases during World War I rather than rising, as do the other two series.

Rees's evidence, like Douglas's, was indirect and only by inference could he conclude that immigrants had only a very small impact on the real wages of American manufacturing workers. He did not directly estimate the effect of immigration on the wages of workers. To get a more direct estimate of the economic impact of immigrants would require a cross section of labor markets each receiving immigrants in different proportions to the existing population. But a single cross-section of cities may be insufficient. Immigrants sought particular labor markets that paid high wages. Whth city-level observations for two cross sections one can estimate a difference equation that gets around part of the simultaneity problem. Ironically, the same data that both Douglas and Rees used to construct their nominal wage series are precisely those that contain the type of observations needed and used in this study.

Data on hourly and weekly wages for particular occupations and industries by city are available for much of the period of interest, athough they are not uniform across the entire period. For the 1890 through 1907 period there are the BLS wages and hours series for non-unionized employees that were used by Paul Douglas and Albert Rees, among others. As many as 100 cities were surveyed for each of about twenty occupations with information on hourly eamings given annually. For the 1907 to 1923 period the BLS wages and hours series covers unionized workers in 13 occupations across 66 cities.

In the data from 1890 to 1907, two groups of occupations have been selected for study. The first inchudes four types of laborers - working in foundries, by contract on streets and sewers, in municipal street and sewer work, and in the building trades as common laborers and as hod carriers. A second group includes skilled workers - painters, bricklayers, plasterers, plumbers, and machinists working in foundries and machine shops. The series through 1903 is contained in the 19th Annual Report of the Commissioner of Labor (U.S. Commissioner of Labor 1905) and is continued through 1907 in the subsequent BLS wages and hours series, although with a 
reduced number of cities. After 1907 the series covers only unionized employees by occupation. In the data from 1907 to 1923 there are only skilled workers and their helpers - bricklayers, carpenters, wiremen and their helpers, painters, steamfitters and their helpers, and iron finishers and their helpers. Both sets of data - those for the nonunionized sample and the unionized contain hourly wages by year and occupation for a large number of cities. That for the nonunionized group contains the number of workers in the occupation-city cell, whereas that for the unionized group does not.

Among the building tradesmen, laborers had about the same proportion new and recent immigrants as did the entire goods-producing labor force. Painters and masons, however, were disproportionately native born (see Table 3), although a large fraction of the masons were older immigrant groups, such as Germans. Among street and sewer workers 22 percent were the new and recent immigrants whereas only 12.2 percent of all in the entire goods-producing sector were, yielding a relative proportion of $1.8 .^{20}$

City-level earnings data can also be found in the censuses of manufacturing for 1899 , 1904, 1909, and 1914. The data in this source are by industry, not occupation. They are, in addition, for all employees, not just adult males, although for some of the industries men were the bulk of the labor force. Annual eamings per employee, not hourty wages, are available for each of the four years considered.

Four industries - men's clothing, printing and publishing, bread and bakery products, and foundries - were chosen to span the various characteristics of workers and products. The most serious constraint on the choice of industries was that the number of citles represented had to be substantial and not many industries were found in a large enough sample of cities. Further, the choice of industries was governed by the skills and ethnic composition of workers. The nature of the product, as will be apparent soon, was also a consideration.

\footnotetext{
20 The data on street and sewer workers are not included in Table 3. Foreign born workers were 49.4 percent of all street laborers, the new immigrants were 30.5 percem, and the new and recent immigrants were 22.0 percent.
} 
Men's clothing hired immigrant labor to a very large extent, particularly tailors who came to America with training and who worked in the production of coats that were traded nationally. Printing and publishing, at the other end of the spectrum, hired more highly educated laborers and very few Immigrants - only 2 percent of its work force were new and recent immigrants (Table 3, col. 3). The product was often locally-consumed newspapers. Bread and other bakery products, like men's clothing, had large numbers of immigrants among its workers, was found in virtually every city, and like printing and publishing, its product was generally nontraded. Foundries hired a mixture of skills, and produced a nationally traded good. Although foundry laborers were disproportionately new and recent immigrants, few machinists were. Product demand is important in understanding the impact of immigration on the wages of natives. Immigrants increase the demand for all types of goods but their impact on local wages will be greater and more positive. if these goods are produced locally. In terms of the two main determinants of the impact of immigration on wages, the four industries considered here can be categorized by the following matrix:

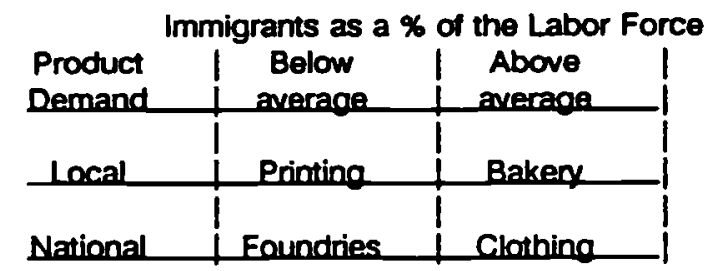

The Economic Impact of Immigration on Local Labor Markets

The objective of this section is to estimate the impact of immigration on the wage outcomes of native-born workers, in part to assess whether immigration restriction was motivated by economic concerns. Immigration to particular cities, like that to particular countries, was not exogenous. Rather, immigramts went to cities that had the highest wages. Thus a simple crosssection regression of city-level wages on the percentage immigrant yields a strong positive coefficient, as is apparent in the regression coefficients in Table 5.

Certain chies could have had higher demand curves for less skilled labor than did ohers. 
Table 5

Cross-Sectional Relationship between Immigrant Flow and City Wages

A. Regression of hourty wages on fraction immigrant l(foreign bom in $t+10$ - foreign bom in $t) /($ average population from $t$ to $t+10)$ ], by city for various occupations, 1890 to 1910

Occupations

Using 1893 Wage, No. Obs. Using 1903 Wage, No. Obs.

Elasticity" Elasticity"

Laborers and

hod carriers

0.094

192

0.135

192

Building trades and

machinists

0.101

278

0.082

278

B. Regression of annual earnings on fraction immigrant [(foreign born in $t+10$ - foreign born in $t) /($ average population from $t$ to $t+10)$ ], by city for various industries, 1900 to 1910

$\begin{array}{lcr}\text { Industries } & \begin{array}{c}\text { Using } \\ \text { Elasticity }\end{array} \\ \text { Bakery } & & \text { No. Obs } \\ \text { Clothing } & 0.126 & 108 \\ \text { Foundry } & 0.125 & 48 \\ \text { Printing } & 0.078 & 101 \\ & 0.092 & 105\end{array}$

a The elasticities are evaluated at the means from a regression of the wage in the given year on the percentage of the city population that was immigrant, where immigrant $=$ (foreign born in year $t+10$ ) . (foreign born in year $t$ ). The regressions are weighted by the number of workers in each occupation-city cell or in each city-industry cell.

Sources:

By occupation: U.S. Commissioner of Labor (1905).

By industry: U.S. Bureau of the Census, Census of Manulactures (various years)

Population: U.S. Bureau of the Census, Census of Population (various years). 
If this higher demand were a permanent feature of the city, as opposed to one that was transitory, there is a simple way around simultaneity. The method is to estimate a difference equation. The difference in the (log of) wages for a group of workers is regressed on the difference in the percentage of the population (or the labor force) that is immigrant. The procedure, which estimates a fixed-effect model, assumes that, for each city $i$, the (log) wage at time $t .\left(w_{w}\right)$, is a function of the percentage foreign born, $\left(F_{k}\right)$, and an error term consisting of a portion that may be correlated with $F_{i n}\left(c_{i}\right)$ or the fixed effect, and a portion that is not, $\left(\mu_{i}\right)$ :

$$
\ln \left(w_{n}\right)=\beta_{0}+\beta_{1}\left(F_{n}\right)+c_{1}+\mu_{n}
$$

If equation (1) were estimated, the coefficient of imerest, $\hat{\beta}_{1}$, would be biased because cities that have positive demand shocks will have both high wages and a high percentage foreign born. By first differencing (and dropping the i subscripts) we get:

$$
\begin{gathered}
\text { In }\left(w_{1+1} / w_{)}\right)=\beta_{1}\left(F_{t+1}-F_{1}\right)+\mu, \text { that is } \\
\Delta \ln w=\beta_{1} \Delta F_{t}+\mu
\end{gathered}
$$

(see Altonji and Card 1991 for the hunctional form derivation). ${ }^{27}$ Note that $\hat{p}_{1}$, which under the assumptions is now unbiased, is the percentage change in the wage of a particular group (e.g., artisans, laborers, workers in some industry) in response to a percentage point change in the proportion of the population (or labor force) that is foreign bom.

Because immigrants can increase the demand for particular products and thus the labor that produces them, as well as compete with or complement other labor, the sign of $\beta_{1}$ is ambiguous a priori. If the group in question is unskilled labor and if the foreign bom are disproportionately unskilled, then $\beta_{1}$ can be less than or equal to zero. If the reference group were skilled labor, however, $B_{1}$ could be positive. ${ }^{20}$

27 If the error term also consisted of a time dependem componem, not orthogonal to $F_{p}$ it would not be first differenced away and could serve to bias the coefficient. Transitory demand shocks would be such a factor and would serve to upwardly bias $\beta_{1}$.

28 There are two cases, one each for skilled and unskilled labor. Attoni and Card (1991) present the unskilled case. The skilled case is easily derived from their model and is given by:

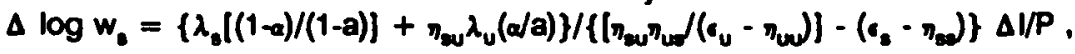


In addition to the potential blases already mentioned is the possibility that labor, either native-born or prior immigrant workers, migrated from cities in which recent immigrants landed. This bias would result if recent immigrants drove away previous workers by reducing wages, increasing the price of housing, or through a general dislike of the newer immigrant groups. Such groups would then decrease wages in other cities that had fewer immigrants. If mobile workers tend to equalize wages across cities, the econometrician's data will show little or no effect when there was a negative effect for all workers of that skill level. ${ }^{20}$ "Spillovers" of this type bias $\beta_{1}$ toward zero. The facts for the period under consideration, however, do not suggest that nativeborn and already-settled foreign-born workers were moving away from areas to which recent immigrants went in the 1900 to 1910 period. Rather, they were moving in. Although spillover effects could still bias the relevant coefficient to zero, there is no evidence that the bias was large. 30

The estimates of equation (2) are presented in Table 6 for the nonunion occupation sample (1890 to 1907), the union occupation sample (1907 to 1923), and the industry sample (1899 to 1914). The data for the percentage foreign born, from the census, is often, but not always, for the nearest census dates. In most cases, the impact of immigration is allowed to take

where $\mathrm{s}=$ skilled labor, $\mathrm{u}=$ unskilled labor, $\mathrm{a}=$ proportion of population that is unskilled, $a=$ proportion of immigrants who are unskilled, the $\eta$ 's are usual elasticities of substitution, the e's are usual supply elasticities, $I=$ immigrants, and $P=$ population, and $0 \leq \lambda \leq 1$. The $\lambda$ 's are a function of the degree to which the product is internally or externally consumed. To the extent it is consumed by residents of the local labor market, the positive impact of immigration on wages is enhanced. Note that if $\eta_{m u}$ is positive, that is the inputs are relative substitutes, the effect of immigrants on the wages of the reference group must be $\leq 0$. Only if the inputs are relative complements could the impact of immigration on the wages of the reference group be positive. Because immigrants were disproportionately unskilled, the impact of their increase on the wages of the unskilled would have to be nonpositive. But there is reason to view the skilled and unskilled as complementary, at least in the short run. If the goods produced by the skilled (e.g., housing) are demanded by immigrants, the wages of the skilled could rise with increase immigration.

29 The result will also hold if the effect were to increase wages in occupations having workers complementary to immigrants.

${ }^{30}$ See, for example, Borjas, Freeman, and Katz (1992) on estimating the economic impact of immigrants in a framework that attempts to circurnvent the spillover problem. 
Table 6

Percentage Change in Wages with a Percentage Point Change in the Proportion Foreign Born:

City-Level Observations, 1890 to 1914, by Occupation or Industry

By Occupation, Nonunion", Hourly Wage

\begin{tabular}{|c|c|c|c|}
\hline 1890 to 1897 & -0.010 & $(-0.053)$ & 192 \\
\hline 1890 to 1903 & -1.02 & $(-2.98)$ & 192 \\
\hline 1890 to 1907 & -1.60 & $(3.39)$ & 160 \\
\hline \multicolumn{4}{|l|}{ Artisans ${ }^{c}$} \\
\hline 1890 to 1897 & 0.679 & (2.92) & 278 \\
\hline 1890 to 1903 & -0.539 & $(-1.88)$ & 278 \\
\hline 1890 to 1907 & -0.145 & $(-0.33)$ & 162 \\
\hline \multicolumn{4}{|c|}{$\begin{array}{l}\text { Occupation, Union", Weekly Wage } \\
\text { Artisans }\end{array}$} \\
\hline 1907 to 1915 & -1.44 & $(-3.27)$ & 223 \\
\hline 1909 to 1915 & -1.20 & $(3.58)$ & 223 \\
\hline 1907 to 1923 & -1.60 & $(-2.81)$ & 225 \\
\hline 1909 to 1923 & -1.41 & $(-2.65)$ & 225 \\
\hline \multicolumn{4}{|l|}{$\begin{array}{l}\text { Industry. Annual Wage } \\
1899 \text { to } 1914\end{array}$} \\
\hline Bread \& bakery products & 0.418 & $(0.69)$ & 107 \\
\hline Clothing, men's ${ }^{d}$ & 3.06 & $(-2.45)$ & 27 \\
\hline Foundry & -0.829 & $(-1.92)$ & 91 \\
\hline Printing \& publishing & 0.764 & (1.47) & 104 \\
\hline
\end{tabular}

- The change in the percentage foreign born is for the 1890 to 1900 decade for the nonunion occupation data, and 1910 to 1920 for the unionized occupation data. That by industry uses 1900 to 1910.

b Laborers include: laborers in building trades, in foundries, and in streets and sewer work (municipal city and contract) and hod carriers.

c Nonunion artisans include: building tradesmen (bricklayers, carpenters, painters, plasterers, and plumbers) and machinists in foundries. Union artisans include: bricklayers, carpenters, wiremen, painters, steamfitters, and structural iron finishers.

Excludes firms that do not remain in the sample to 1919 and the observation for New York City.

Notes: t-statistics are in parentheses. Regressions are estimated for each group of occupations or each industry. The dependent variable is the difference in the $\mathrm{log}$ of wages between the end and beginning years. All regressions have been weighted by the average number of sample workers in the interval, except those for the union sample where the weights are the log of city population. The growth rate of the white population (difference of the logs of the white population between the end and beginning years) is also included as an independent variable in the regressions.

Sources:

By occupation. nonunion: 1890 to 1903, U.S. Commissioner of Labor (1905); 1907, Department of Commerce and Labor (1908).

By occupation, union: data provided by Shawn Kantor, from U.S. Department of Labor (various years). By industry: U.S. Bureau of the Census, Census of Manufactures (various years).

Population: U.S. Bureau of the Census, Census of Population (various years). 
effect over several years (e.g. 1890 to 1903 uses population data for 1890 and 1900 ).

The estimates of the impact of immigrants on the wages of laborers are generally negative and often substantial, particularly for the period extending into the twentieth century. Only the artisan sample covers both the 1890 to 1907 and the 1907 to 1923 periods, and it shows some increase in magnitude with time. In general, a one percentage point increase in the population share that was foreign born decreased wages by about 1 to 1.5 percent. ${ }^{31}$

Interestingly, the negative effects of immigration on the wages of both the unskilled and skilled occupations for the 1890 to 1903 (or 1907) period were not recorded for the 1890 to 1897 period. $^{32}$ Wages were extremely rigid during the period of the 1890 s depression and only began to respond to the various labor market shocks with the large change in prices after 1898. Thus when the literacy test came before Congress for the first and second times (1897 and 1898), capltal may not yet have benefited from the wage effects of immigration but labor was still reeling from unemployment. By 1904 when capital had swung to the pro-immigration, anti-literacy test camp the wage effects were, in some cases, quite strong.

The industry results conform to the predictions regarding the roles of labor composition and product demand. In men's clothing, which contained a large proportion of immigrants, wages were distinctly depressed in cities having an increase in the percentage of their populations that was foreign bom from 1899 to 1909 . The decrease is substantial: a 1 percentage point increase in the fraction of the city's population that was foreign bom decreased wages by about 1.5 to 3

31 The union sample uses weekly rather than hourty wages, while that for the non-union workers uses hourty wages. In the non-union sample, hourty wages are a separate entry, whereas the union sample has weekly wages for a union contract as well as the contract hours for the week. Regressions using the implied hourty wage do not yield coefficients that differ much from those using the weekly wage for the union sample, but the standard errors are larger.

32 Note that the population data exist only for 1890 and 1900, but this is not the reason for the differences between the 1890 to 1903 regressions and that for 1890 to 1897 . The real reason is to be found in the stickiness of wages, which may have been the single most important factor giving rise to large unemployment in the 1890s. A significant fraction of the cities had no change in nominal wages from 1890 to 1897 , but wages changed rapidly in the face of price changes after 1897 . 
percent. Foundries also show negatlve and, at times, statistically and quantitatively significant coefficients. Because foundries hired both skilled (native) and unskilled (foreign-born) workers (see Table 3), the results are even more supportive of the view that immigration severely depressed the wages of less skilled labor.

The other two industries considered show small, generally insignificant, if not positive, coefficients. The absence of a negative effect in printing and publishing, indeed the presence of a positive effect, may not be surprising. Most printing establishments employed skilled and native-bom labor, and produced a locally consumed good the demand for which would have risen with immigration. ${ }^{33}$ The small, positive, but ahways statistically insignificant effects of immigration on the wages of workers in bakeries may, as in the printing and publishing case, be due to the positive demand effect of immigration on a locally consumed good. Bread was, and is, the staff of life, but was even more so for immigrant and poor populations in America ${ }^{34}$

It should be noted that the generally negative impact of immigration on the wages of both lower-skilled and higher-skilled workers could not be caused by the simple addition to the working population of lower-waged workers. The mean wage is no more than a simple average of the wages of native and foreign-born workers. If immigrants eam less than natives by virtue of their lack of certain skills or by dint of labor market discrimination, then the mean wage will be depressed by the increase in foreign-born workers. But the depressing impact of the foreign born on the wage occurs for the artisan group, which included very few of the new and recent foreign

23 The largest positive effect would occur in an industry hiring both skilled and unskilled (or native and immigrant) labor in which the two types of labor are complementary and the good is locally consumed in its entirety, if the wages of only the skilled workers were considered. The data, however, consist of a labor force-weighted average of the wages of all workers in the industry.

34 In a simple model of local labor markets the nature of product demand alone cannot generate a positive impact of immigration on wages; one needs complementarity of demand between immigrants and the labor in the occupation or industry. In the case of printing and publishing there were probably both effects. In the case of bakeries it is less likely that both effects operated and thus the existence of a positive coefficient is curious. Even if the wages of (skilled) labor hired by an industry were unaffected by the increase in (primarily unskilled) immigrams, the coeficient would be zero, not positive. See, for example, Altonji and Card (1991). 
born (see Table 3). The difference in wages between immigrant and native for the same occupation would have to be extremely high to account for the large negative impact of immigration on wages in general and even for those occupations in which the foreign born were a large percentage.

\section{Explaining the 1915 Vote to Override Wilson's Veto}

The wage effects of the foreign born suggest a role for economic forces in the movement to restrict immigration. The undertying model is one in which constituents urge their Representative to vote for restriction (that is, to pass the literacy test or to override a Presidential veto) with more force the lower is the increase in wages (or the greater is the decrease in wages). The foreign born may be the cause of the wage change or they may be the scapegoats for other economic influences. But, at the same time, if a large enough fraction of the constituents were themselves foreign born, they would probably urge their Representative to vote against restriction. Table 7 explores these two factors in determining the House vote in 1915 on the override of President Wilson's ficst veto of the literacy test. The data are by city for the union-occupation sample, whereas the votes are by Congressional district. I have matched the cities to the districts in the 63rd Congress. For those cities covering more than one Congressional district, the dependent variable is the fraction of Representatives who voted to override the veto. The estimation is performed for all city-occupation observations in the union data set and for the nonSouth subset as well. Southem cities were typically small and voted ovenwhelmingly to override Wilson's veto.

In both samples (all cities and the nonsouth) an increase in the wage by occupation, from 1907 to 1915, decreased the proportion of votes for the override. A vote for the override was a vote against open immigration, thus the lower the wage increase, the less support for open immigration. Increasing the wage change by one standard deviation in the nonsouth sample (a 13 percent increase) would decrease the percemage voting against open immigration by 12 
Table 7

Explaining the House Vote in 1915 on the Literacy Test

\begin{tabular}{|c|c|c|c|c|c|c|}
\hline \multirow[b]{2}{*}{$\begin{array}{l}\text { Dependent variable: Vote to } \\
\text { override Presidential veto" }\end{array}$} & \multicolumn{2}{|c|}{ All Cities } & \multicolumn{2}{|c|}{ NonSouth } & \multicolumn{2}{|c|}{ Means } \\
\hline & $\hat{\beta}$ & s.e. & $\hat{\boldsymbol{\beta}}$ & s.e. & $\begin{array}{l}\text { All } \\
0.402^{b}\end{array}$ & $\begin{array}{l}\text { NonSouth } \\
0.344\end{array}$ \\
\hline Log (population ${ }_{1910}$ ) & -0.114 & $(0.034)$ & -0.0552 & $(0.036)$ & 12.6 & 12.9 \\
\hline$\left(F B_{1920}-F B_{1910}\right) / F B_{1910^{c}}$ & 0.268 & $(0.104)$ & -0.0480 & $(0.122)$ & 0.082 & 0.088 \\
\hline $\begin{array}{l}\text { Proportion foreign born in po } \\
\qquad \begin{aligned} 1 & =0<.1 \\
1 & =.1<.2 \\
1 & =.2<.3\end{aligned}\end{array}$ & $\begin{array}{l}0.442 \\
0.265 \\
0.256\end{array}$ & $\begin{array}{l}(0.120) \\
(0.110) \\
(0.099)\end{array}$ & $\begin{array}{l}0.124 \\
0.402 \\
0.336\end{array}$ & $\begin{array}{l}(0.206) \\
(0.114) \\
(0.092)\end{array}$ & $\begin{array}{l}0.287 \\
0.244 \\
0.321\end{array}$ & $\begin{array}{l}0.029 \\
0.271 \\
0.479\end{array}$ \\
\hline $\log \left(\text { wage }_{1915} / \text { wage }_{1907}\right)^{\bullet}$ & -0.461 & $(0.219)$ & -0.913 & $(0.256)$ & 0.179 & 0.173 \\
\hline $\begin{array}{l}\text { Proportion in political party:' } \\
\text { Republican } \\
\text { Third Party }\end{array}$ & $\begin{array}{l}0.181 \\
0.492\end{array}$ & $\begin{array}{l}(0.080) \\
(0.123)\end{array}$ & $\begin{array}{l}0.210 \\
0.436\end{array}$ & $\begin{array}{l}(0.074) \\
(0.120)\end{array}$ & $\begin{array}{l}0.248 \\
0.065\end{array}$ & $\begin{array}{l}0.354 \\
0.096\end{array}$ \\
\hline Constant & 1.52 & $(0.491)$ & 0.799 & $(0.517)$ & & \\
\hline $\begin{array}{l}\mathrm{R}^{2} \\
\text { Number of observations }\end{array}$ & $\begin{array}{l}0.25 \\
209\end{array}$ & & $\begin{array}{l}0.31 \\
140\end{array}$ & & & \\
\hline
\end{tabular}

Notes: Also included is a dummy variable for the city of Boston.

Sources: Voting data from Congressional Record; wage data from source in Table 6.

\footnotetext{
- A vote to override the Presidential veto $(1=$ vote to override) was a vote for immigration restriction. Most cities in the sample contain one congressional district, but almost all of the large cities contain several. A split vote was treated as the fraction voting for the override. Absent congressmen who "paired," in this case pairs were actually 2 to 1, were allocated on the basis of their stated preference for or against the override. There were very few congressmen absent for this vote; see Table 1.

b The percentage voting to override the veto was considerably smaller in this sample than in the nation as a whole because urban congressmen voted more overwhelmingly against immigration restriction than did congressmen from rural America.

$\mathrm{FB}=$ foreign born

C Cities with more than $30 \%$ foreign bom are the omitted class. Foreign bom is as of the 1920 census, because immigration was very low after 1914 to the end of World War I. The figure in 1920 census, therefore, most accurately reflects the composition of cities in 1915, at the time of the vote.

- The wage change is by city for the union occupations described in the notes to Table 6 . There can be several observations per city, depending on the number of occupations represented in the sample.

Democrat is the omitted political party. In cities having more than 1 congressional district, these variables are the proportion of each political party in all the districts comprising the city. Thus, these are not true dummy variables, athough there are few cities having Representatives from different parties.

- Third parties include Progressive and Progressive Republican.
} 
percentage points. The percentage foreign born in the city was an even more powertul determinant of the vote. The proportion foreign born is divided into 4 groups, which in the total sample about evenly divide the cities. In the nonsouth group, however, there are very few in the smallest class of percent foreign born. With the exception of these fow small cities, increasing the percentage foreign born greatly decreases the probability of voting against the override. When the foreign born are about 30 percent of the total population, almost all Representatives vote against the override.

The estimation underscores the critical importance of reinforcing flows of immigration in building and maintaining the open immigrant vote. Flows that were reinforcing increased the fraction foreign born to the critical level needed to produce votes against overriding the veto. Flows that diluted, however, raised the proportion foreign born in the intermediate range, but not to the higher level required to keep the restrictionist forces at bay. Recall that flows were reinforcing trom 1900 to 1910 but were diluting from 1910 to 1920 . Had the distribution of percemage foreign bom been at its 1910 level, rather than the level recorded by 1920, the vote for restriction would have been reduced by about one-third in the sample cities. ${ }^{35}$ Note, as well, the importance of the (log of 1910 population variable. The greater the total population, the lower is the vote to override, that is the greater is the expressed sentiment for open immigration. The reason complements that on the percentage foreign born. With a greater population there is more room for minorties segregared in enclaves to gain a Representative.

${ }^{35}$ Using the 1910 figures, $43 \%$ of the nonSouth cities (actually city-occupation observations) had percentage foreign born $>30 \%$, but only $22 \%$ did using the 1920 figures. Multiplying the percentages in the dummy foreign-bom categories by the coefficients in Table 7 and differencing yields an increase of 0.0785 from 1910 to 1920 for the nonSouth sample. The 1915 vote in the nonSouth urban sample is 0.344 . If the 1910 percentage foreign born data were used, the vote would have been 0.266 or $30 \%$ less. 
Summary and Conclusions

The curtailment of immigration, codified in the 1921 Emergency Quota Act and in subsequent laws culminating in the National Origins Act, was heralded for twenty-five years. That immigration was not restricted from sometime in the mid-1890s to World War I was the result of shifting political interests, generally good times, and a lot of good luck for Europe's poor and oppressed.

Restrictive legislation was almost passed in 1897 and again in 1898. Had but two members of the House changed sides in 1898 the literacy test would have become law. It is doubtful that McKinley, having run on a platform calling for the literacy test - the only such platform in the pre-restriction period - would have vetoed it. Restrictionist sentiment then abated. An economic recovery tumed the interests of capital around, and the flood of immigrants of the earty 1900 s reinforced pro-immigration constituencies in various big-city districts. But the rest of America moved toward restriction. The South had been lost by the 1906 vote at the latest. The new immigrants had gone North and West, rarely South, and were, to southem eyes, too dark to be assimilable..$^{30}$ The rest of urban and industrial America felt some downward pressure on wages from the new immigrants but not the political pressure from the vast numbers that clustered in the big-city districts. Capital maintained its pro-immigration stance to the bitter end, when all but the big-city vote went to the anti-immigram camp. The period from the 1913 vote to that which was successtul in 1917 was just a matter of waiting for some exogenous force - an economic downturn, a war, a rash of labor unrest - to close the door. That 17 million slipped through from 1897 is the miracie.

This study has looked primarily at urban votes and the twin forces of economics and demography in the drive for immigration restriction. Although the American population was still

36 See, for example, the speech of Senator Simmons of North Carolina during the 1906 debates in which he said: "The broad fact, then, is that about two-thirds of all the immigration to this country to-day and during recent years has come from southern and eastern Europe ... They belong . . . to a different civilization from that represented by the Anglo-Saxon race* (U.S. Congress, Congressional Record Senate, vol. ?, p. 7295). 
predominantly rural in 1910, the battle for immigration restriction was fought in the cities. Rural America was almost uniformly in favor of immigration restriction as early as the 1897 vote. Only the South switched sides, joining the American heartland in its opposition to unrestricted Immigration. Urban America moved strongly into the pro-lmmigration camp as its ever-Increasing foreign born constituency gained the vole. But even in the nation's large cities, the economic impact of immigrants on the economic status of native-born workers heavily impacted proimmigration sentiment. And it was the withering away of the urban pro-immigration vote that ultimately closed the door. 
Altonii, Joseph G. and David Card. (1991) The Effects of Immigration on the Labor Market Outcomes of Less-skilled Natives." In John Abowd and Richard Freeman, eds., Immigration. Trade, and the Labor Market. Chicago: University of Chicago Press, pp. 407-21.

Borjas, George J., Richard B. Freeman, and Lowrence F. Katz. (1992) "On the Labor Market Effects of Immigration and Trade. in George J. Borjas and Richard B. Freeman, eds., Immigration and the Work Force: Economic Consequences for the United States and Source Areas. Chicago: University of Chicago Press, pp. 213-244.

Coombs, Whitney. (1926) The Wages of Unskilled Labor in Manufacturing Industries in the United States, 1890-1924. New York.

Devid, Paul A., and Peter Solar. (1977) "A Bicentenary Contribution to the History of the Cost of Living in America." In P. Uselding, ed., Research in Economic History, vol. 2 New York: JAl Press: 1-80.

Douglas, Paul H. (1930) Real Wages in the United States, 1890-1926. Boston: Houghton.

Easterlin, Richard. (1981) Why Isn't the Whole World Developed? Journal of Economic History (March): 1-20.

Ferenczi, Imre, and Walter F. Willcox. (1929) Imternational Migrations, vol. I Statistics. New York: National Bureau of. Economic Research.

Hannon, Joan. (1982) "Ethnic Discrimination in a Nineteenth Century Mining District: Michigan Copper Mines, 1888," Explorations in Economic History (Jan. 1982): 28-50.

Hatton, Timothy J., and Jeffrey G. Williamson. (1992) Imternational Migration and World Development: A Historical Perspective." Harvard Institute of Economic Research Working Paper No. 1606.

Heald, Morrell. (1953) "Business Attitudes Toward European Immigration, 1880-1900." Journal of Economic History 13 (Summer?): 291-304.

Higham, John. (1981, 1st publ. 1955) Strangers in the Land: Patterns of American Nativism, 18601925. Westport, CT: Greenwood Press.

Hutchinson, E. P. (1981) Legislative History of American Immigration Policy: 1798-1965. Philadelphia: University of Pennsylvania Press.

Jones, Maldwyn Allen. (2nd ed. 1992, 1st publ. 1960) American Immigration. Chicago: University of Chicago Press.

Keyssar, Alexander. (in progress) -Notes on the Voting Strength of the Foreign Born in Large Cities, 1900 to $1920 .^{\circ}$

Long, Clarence. (1960) Wages and Eamings in the United States, 1860-1890. Princeton: Princeton University Press for the NBER. 
Rees, Albert. (1975, 1st publ. 1961) Real Wages in Manufacturing, 1890-1914. New York: Arno Press.

Simkovich, Boris, Alan Taylor, and Jeffrey G. Williamson. (1992) The Evolution of Global Labor Markets: Appendix." HIER Working Paper No.

Taylor, Philip. (1971) The Distant Magnet: European Emigration to the U.S.A. London: Eyre and Spottiswoode.

U.S. Bureau of the Census. (various years) Census of Manufactures. Reports by States, with Statistics for Principal Cities. Washington, D.C.: GPO.

U.S. Bureau of the Census. (various years) Census of Population. Washington, D.C.: GPO.

U.S. Bureau of the Census. (1975) Historical Statistics of the United States: Colonial Times to 1970. Washington, D.C.: GPO.

U.S. Commissioner of Labor. (1905) Nineteenth Annual Report, 1904. Wages and Hours of Labor. Washington, D.C.: GPO.

U.S. Congress. (various years) Congressional Record. Washington, D.C.: GPO.

U.S. Congress. (various years) Congressional Directory. Washington, D.C.: GPO.

U.S. Department of Commerce and Labor. (1908) Bulletin of the Bureau of Labor No. 77, Wages and Hours of Labor. Washington, D.C.: GPO.

U.S. Department of Labor. (various years, 1907 to 1923) Union Scales of Wages and Hours of Labor. Washington, D.C.: GPO.

U.S. Senate Document. (1911a) Reports of the Immigration Commission. Abstracts of Reports of the Immigration Commission, Vol. 1. Document No. 747, 61st Congress, 3rd Session. Washington, D.C.: GPO.

U.S. Senate Document. (1911b) Reports of the Immigration Commission, Vol. $1-42$ (also known as the Dillingham Commission Reports). Washington, D.C.: GPO.

Wiebe, Robert H. (1962) Businessmen and Reform. Cambridge, MA: Harvard University Press.

Willcox, Walter F. (1931) Imternational Migrations. Vol. II Imterpretations. (New York: National Bureau of Economic Research).

Williamson, Jeftrey G. (1982) Immigrant-Inequality Trade-Offs in the Promised Land: Income Distribution and Absorptive Capacity Prior to the Quotas." In Barry Chiswick, ed., The Gateway: U.S. Immigration Issues and Policies. Washington, D.C.: American Enterprise Institute, Pp. $251-88$.

Wiltiamson, Jeffrey G. (1980) American Inequality: A Macroeconomic History. New York: Academic Press. 